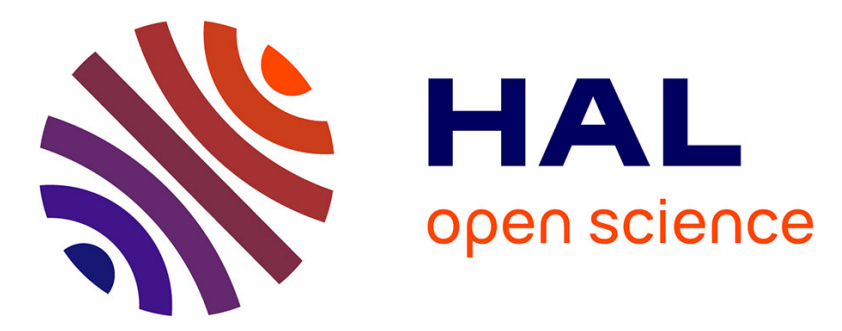

\title{
Measuring and improving the performance of customs valuation controls: An illustration with Gabon
}

\author{
Joël Cariolle, Cyril Chalendard, Anne-Marie Geourjon, Bertrand Laporte
}

\section{To cite this version:}

Joël Cariolle, Cyril Chalendard, Anne-Marie Geourjon, Bertrand Laporte. Measuring and improving the performance of customs valuation controls: An illustration with Gabon. The World Economy, 2019. hal-03462497

\author{
HAL Id: hal-03462497 \\ https://hal.uca.fr/hal-03462497
}

Submitted on 1 Dec 2021

HAL is a multi-disciplinary open access archive for the deposit and dissemination of scientific research documents, whether they are published or not. The documents may come from teaching and research institutions in France or abroad, or from public or private research centers.
L'archive ouverte pluridisciplinaire HAL, est destinée au dépôt et à la diffusion de documents scientifiques de niveau recherche, publiés ou non, émanant des établissements d'enseignement et de recherche français ou étrangers, des laboratoires publics ou privés. 


\title{
Measuring and improving the performance of customs valuation controls: An illustration with Gabon
}

Joël Cariolle, Fondation pour les études et recherches sur le développement international (Ferdi), joel.cariolle@ferdi.fr.

Cyril Chalendard, CERDI, University of Clermont Auvergne, Cyril.chalendard@ gmail.com

Anne-Marie Geourjon, Ferdi, ageourjon@ ferdi.fr

Bertrand Laporte, CERDI, University of Clermont Auvergne, bertrand.laporte@uca.fr

\begin{abstract}
Modern customs administrations aim to both facilitate legal trade and combat fraud. To meet this dual objective, many customs administrations in developing countries must give risk management a highly prominent role. In this context of modernization, this article first provides stylized facts on the performance of the customs controls carried out at the Gabon border. Then, we compare Gabon's granular import customs data with international trade statistics. Based on this comparison, we identify undetected fraud and develop a methodology to target ex post audits. Finally, we define indicators to monitor the performance of customs valuation controls. To improve their performance, we show that customs in developing countries should rely more on data analytics, notably via the implementation of simple statistical tools and the diversification of their sources of information.
\end{abstract}

JEL codes: H26, H83, K42, D73, F13 


\section{Introduction}

Trade liberalization, which intends to bring greater social welfare, can only be successful if efficient trade-related institutions are in place. In many countries, the lack of far-reaching reforms to private and public trade institutions has jeopardized the positive effects of trade liberalization. Among the institutions that play an important role in trade liberalization policy, customs administrations are at the forefront. In developing countries, the mission of customs administrations has deeply changed in recent years due to World Trade Organization (WTO) and World Customs Organization (WCO) agreements. Trade facilitation became a priority for promoting customs modernization, on the one hand, even if improved revenue mobilization remains the primary objective of customs reform on the other. Therefore, a major challenge is to identify the most effective ways to address these two potentially conflicting objectives.

In fact, corruption is prevalent in trade institutions, especially in customs administrations (Sequeira, 2016), so that only a few countries capture all the potential benefits of liberalization. In many lowincome countries, moral hazard has resulted in widespread corruption (collusion, blackmail, extortion, etc.) that the incentives/sanctions system had failed to prevent. The incentives system (bonuses, promotions, recognition, etc.) is far from compensating for the revenues derived from corruption, and very few sanctions are effectively applied to corrupt customs officers. For this reason, many developing countries have embarked on ambitious plans to reform their customs administration, a key element of comprehensive reforms to fight corruption and encourage good governance (Keen, 2004: Yang, 2008).

To address the problem of imperfect information that characterizes any customs clearing operation that is, the moral hazard related to stakeholder integrity and adverse selection as related to actual import characteristics - a number of governments have resorted to using private companies to reduce information asymmetries through pre-shipment or destination inspections (Yang, 2008). However, in most countries, customs keeps the prerogative of physically controlling imports and questioning the information provided by these private companies, so moral hazard remains strongly present (Dutz, 2000, Johnson, 2001, Dequiedt et al., 2009). The involvement of private companies in import 
inspections is even found to lengthen clearance procedures, increase transaction costs and thereby hinder trade facilitation (Dutz, 2000). As a result, limiting the physical inspections of goods is a key issue in promoting trade facilitation and in pushing for a change in the mentality required to effectively modernize customs administrations. This development is fully in line with the revised Kyoto Convention (WCO agreement), the general objective of which is to standardize and harmonize customs procedures worldwide based on the three following major principles: simplification, automation and efficiency.

How can legal trade be facilitated while also effectively combatting fraud? Over the past several years, customs administrations in developing countries, aware of the need to modernize their services, have tried to meet these dual objectives by developing risk analysis to reduce and improve customs controls. Long-term projects have therefore been implemented in many developing countries to improve the risk analysis and selectivity of controls ${ }^{1}$ based on information on customs detected fraud. The results are encouraging, especially in terms of trade facilitation, and often exceed the initial objectives. Recent studies have indeed shown that a reduction in inspections and waiting periods favours trade (Fernandes et al., 2015; Martincus et al., 2015). In general, these projects have helped promote a cultural change in the associated administrations by demonstrating the benefits of using statistical and quantitative analysis techniques, in most cases by exploiting data from their customs clearance information systems (Geourjon and Laporte, 2005, 2012; Geourjon et al., 2013).

However, one of the main weaknesses of these initiatives is that fraud risk detection relies solely on fraudulent declarations detected by customs inspectors, which limits the scope of the exercise and its reliability. The outcomes of fraud-based risk analysis depend on customs inspectors' work habits, honesty and skill in a context of moral hazard. They also depend on the number of past frauds detected, which, in the context of customs administrations from developing countries, is often very low, thereby justifying the use of additional sources of information.

\footnotetext{
${ }^{1}$ Many developing countries now use risk management techniques to assess compliance with declarations. For the development of risk analysis and management systems in Latin America and the Caribbean, see Martincus (2016), in Albania, see Fernandes et al. (2015), and in West African countries, see Geourjon and Laporte (2012).
} 
Several studies use statistical discrepancies in international trade data or mirror data to identify declarations with fraudulent classification, quantity, origin or value and to estimate their consequences. $^{2}$ The mirror analysis of bilateral trade consists of comparing, for a given product, the information on exports declared by the exporting country with the corresponding information on imports reported by the importer country to detect discrepancies in quantity, weight or declared value. Bhagwati (1964) was the first to use this method to study customs fraud in Turkey, where he identified a substantial undervaluation of imports for oil products, machines and cars. Carrere and Grigoriou (2015) applied this method to estimate informal flows in international trade and to predict import misclassification. Raballand et al. (2013) also used the analysis of trade discrepancies to estimate customs fraud in Cameroon, while Chalendard et al. (2016) identified high-risk products and operators in Madagascar by combining a mirror analysis with detailed information on declaration behaviours. The latter revealed substantial value and classification frauds (approximately $30 \%$ of collected non-oil revenues).

Moreover, many empirical papers studying the determinants of customs fraud use discrepancies in mirror data as a fraud indicator. Some of these works study the link between customs fraud and import tax rates. By analysing mirror data on trade between China and Hong Kong, Fisman and Wei (2004) estimate that a $1 \%$ increase in taxes is associated with a $3 \%$ increase in fraud. This result could partially explain valuation fraud (undervaluation) and classification fraud (tariff slippage) practices. Such a relationship is also evidenced in India (Mishra et al., 2008), in North America (Stoyanov, 2012), in Central Europe (Javorcik and Narciso, 2008), in Africa (Worku et al., 2016), especially in Mozambique (Van Dunem and Arndt, 2009, Sequeira, 2016), Kenya, Tanzania (Levin and Widell, 2014) and Tunisia (Rijkers et al., 2015).

\footnotetext{
${ }^{2}$ Other studies use mirror data to estimate missing or unreliable data (Anderson and Van Wincoop, 2003; Anson et al. 2006). Since exports are declared free on board (FOB) and imports are declared at cost, insurance and freight (CIF), "export-import" discrepancies represent, in a context of no fraud, the costs of transport, insurance and freight. Thus the mirror data can be used to estimate transports costs (Yeats, 1978; Baier and Bergstrand, 2001; Limao and Venables, 2001; Hummels and Lugovskyy, 2006).
} 
The contribution of this paper is twofold. First, based on the Gabon case study, it confirms that customs authorities in developing countries can greatly improve the effectiveness of their frontline controls, i.e., inspections performed at the border and their overall performances, by matching an external mirror with internal records of fraudulent declarations. ${ }^{3}$ Granular databases including the history of imports for 2013, 2014 and 2015 were constituted and used to separate declarations with a fraud record from those deemed compliant. In this paper, this information on declarations is processed, analysed and compared with the mirror statistics for Gabon's international trade for 2013 and 2014.

This approach illustrates the benefits administrations can obtain by considering other sources of information, which has also been underlined in other studies (Chalendard, 2017). Customs should use all available information - external or internal to the organization - to facilitate legal trade and more effectively fight customs fraud. Second, the paper defines innovative measurement tools, based on the matching of mirror data with internal data on fraud records, to assess the effectiveness of customs controls in a context of poor public governance. Importantly, the resulting indicators can be easily replicated on the ground.

The next section analyses internal data on fraudulent declarations detected by Gabon customs. Section 3 discusses the benefits of using mirror data to detect customs fraud and provides an application of this approach to Gabon customs. Section 4 presents innovative performance indicators for customs controls. Section 5 concludes by discussing the complementary use of internal fraud records and mirror data analysis to improve the overall performance of customs valuation controls in developing countries.

\section{Evidence on the performance of Gabon customs based on internal fraud records}

This section exploits a confidential dataset of Gabon customs internal fraud records to provide novel statistical insights into the effectiveness of customs controls in a developing country. Indeed, such

\footnotetext{
${ }^{3}$ In 2014, the Gabon customs authority planned to develop a project to reduce and improve controls by implementing a system for targeting customs declarations using risk management techniques that exploit customs information systems (Geourjon and Laporte, 2005, 2012; Laporte, 2011).
} 
statistics are original because they are not usually publicly released due to their sensitivity. Retrospective data on Gabon import declarations over the period 2013-2015 are therefore analysed to provide an initial assessment of customs controls effectiveness. This preliminary analysis highlights the weak performance of Gabon customs inspections: while physical controls are almost systematic, the frequency of detected fraud is very low, and adjustments in import value and customs revenues after controls are negligible.

\subsection{Low incidence of fraud records}

Table 1 presents the frequency of fraud records, that is, declarations deemed non-compliant by the customs inspector. Fraud records, expressed as a share of total declarations and disaggregated by frontline control channels ${ }^{4}$, give valuable information about the effectiveness of customs controls. As in many other developing countries, customs inspectors frequently perform physical inspections of shipments but rarely report a fraud. First, the data show that only $1.13 \%$ of declarations were subject to an upward revision, although most declarations (53\%) were oriented towards the physical inspection channel (i.e., the red channel). This pattern does not vary over the period considered, suggesting that the poor performance of controls is structural and that it is necessary to modernize customs. The data also highlight that there is an obvious need to facilitate legal trade, as only $8 \%$ of customs declarations were oriented towards the green channel. The frequency of fraud records for declarations in the yellow and red channels, expressed as a share of total declarations, declined over the period 2013-2015 but more drastically for transactions in the yellow channel between 2013 and 2014. This trend results from customs' inclination to focus their efforts on physical controls. Although physical inspections represent the most efficient type of control for detecting fraud and should be confined to the highest risk declarations, data stress that the type of inspection (documentary or physical) does not affect the probability of a fraud being reported. In fact, the frequency of fraud records for declarations routed to the yellow channel $(0.51 \%)$ is close to the frequency of fraud records for declarations routed to the red channel $(0.62 \%)$. This result suggests that trade can be easily

\footnotetext{
${ }^{4}$ The green, the yellow and the red channels. The green channel is the facilitation channel, which requires neither documentary controls nor physical inspections before imports clearance. The yellow channel corresponds to the documentary control channel, while a physical inspection is required for declarations directed to the red channel.
} 
facilitated by, for instance, reducing intrusive and resource-consuming physical inspections (red channel) without necessarily limiting customs' ability to detect non-compliance (Geourjon et al. 2013). In a more general way, as in many other developing countries, these numbers cast doubt on the benefits of customs controls.

Table 1. Annual trends in fraud records

\begin{tabular}{ccc|cccc}
\hline \hline & $\begin{array}{c}\text { Number of } \\
\text { declarations }\end{array}$ & $\begin{array}{c}\text { Number of declarations } \\
\text { deemed non-compliant }\end{array}$ & \multicolumn{2}{c}{$\begin{array}{c}\text { Declarations deemed non-compliant as a } \\
\text { \% of total declarations }\end{array}$} \\
\cline { 2 - 7 } Green channel & $\mathbf{2 0 1 3 - 1 5}$ & $\mathbf{2 0 1 3 - 1 5}$ & $\mathbf{2 0 1 3}$ & $\mathbf{2 0 1 4}$ & $\mathbf{2 0 1 5}$ & $\mathbf{2 0 1 3 - 1 5}$ \\
Yellow channel & 7,083 & 0 & 0 & 0 & 0 & $\mathbf{0}$ \\
Red channel & 34,971 & 450 & 0.90 & 0.29 & 0.24 & $\mathbf{0 . 5 1}$ \\
Total & 46,651 & 556 & 0.78 & 0.63 & 0.42 & $\mathbf{0 . 6 2}$ \\
\hline \hline
\end{tabular}

Note: the green channel corresponds to the facilitation channel; the yellow channel corresponds to the documentary control channel, and the red channel corresponds to the frontline physical inspection channel.

\subsection{Small upward revisions after controls}

While the previous subsection documents the probability of fraud detection by control channel, this subsection provides complementary insights into the size of revisions, in terms of import value modifications and customs revenues increases, resulting from these controls (tables 2 to 4 ). The first observation is that the magnitude of these revisions is very limited. In fact, revisions made by customs frontline inspectors increased (i) the declared import value by $0.09 \%$ (slightly more than 2 billion CFA francs, equating to 3.4 million Euros) and (ii) collected amounts by $0.19 \%$ (slightly more than 900 million CFA francs, equating to 1.4 million Euros), which in turn increased customs revenues by $0.17 \%$ (slightly more than 800 million CFA francs, equating to 1.2 million Euros). For each declaration deemed non-compliant, Gabon customs increased on average and per declaration (i) the import value by $37.3 \%$ and (ii) the amounts collected by customs by $47 \%$ (see table 4 ). Therefore, based on these observations, the low performance of Gabon customs lies in the low frequency of fraud detection rather than in the size of revisions of the import value or the amount collected.

Table 2. Revisions and changes in the import value (in billions of CFA) 


\begin{tabular}{lcccc}
\hline \hline & \multicolumn{2}{c}{$\begin{array}{c}\text { Import value (in billions of CFA) } \\
\text { Before revisions }\end{array}$} & $\begin{array}{c}\text { Variation, in } \\
\text { billions of CFA }\end{array}$ & Variation, in \% \\
\cline { 2 - 3 } $\mathbf{2 0 1 3}$ & 846 & 847 & 1.29 & 0.15 \\
$\mathbf{2 0 1 4}$ & 784 & 785 & 0.72 & 0.09 \\
$\mathbf{2 0 1 5}$ & 755 & 755 & 0.21 & 0.03 \\
\hline Total & $\mathbf{2 , 3 8 5}$ & $\mathbf{2 , 3 8 7}$ & $\mathbf{2 . 2 3}$ & $\mathbf{0 . 0 9}$ \\
\hline \hline
\end{tabular}

Table 3. Revisions and changes in revenue collection (in millions of CFA)

\begin{tabular}{|c|c|c|c|c|}
\hline \multirow[b]{2}{*}{2013} & \multicolumn{2}{|c|}{$\begin{array}{cc}\text { Revised collected } & \text { Total taxes paid } \\
\text { amounts } & (\text { CD+VAT+ED) } \\
\text { Variation, in millions of CFA }\end{array}$} & \multirow{2}{*}{$\begin{array}{l}\text { Revised collected } \\
\text { amounts } \\
\text { Variation, in \% } \\
0.26\end{array}$} & $\begin{array}{l}\text { Total taxes } \\
\text { paid }\end{array}$ \\
\hline & 460 & 445 & & 0.26 \\
\hline 2014 & 275 & 167 & 0.18 & 0.11 \\
\hline 2015 & 162 & 164 & 0.12 & 0.12 \\
\hline Total & 897 & 775 & 0.19 & 0.17 \\
\hline \multicolumn{5}{|c|}{$\begin{array}{l}\text { Note: collected amounts include total taxes paid to the customs administration - i.e., customs duty (CD), valu } \\
\text { added tax (VAT), and excise duty (ED) - and other taxes owing to other administrations, }\end{array}$} \\
\hline & \multicolumn{2}{|c|}{$\begin{array}{l}\text { Average variation in the revised collected } \\
\text { amount }\end{array}$} & \multicolumn{2}{|c|}{ Average variation in the import value } \\
\hline & in thousands of CFA & in $\%$ & in thousands of CFA & in $\%$ \\
\hline 2013 & 807 & 64.89 & 2,260 & 52.83 \\
\hline 2014 & 1,023 & 41.57 & 2,690 & 31.82 \\
\hline 2015 & 971 & 35.55 & 1,275 & 27.26 \\
\hline 2013-2015 & 934 & 47.34 & 2,075 & 37.30 \\
\hline
\end{tabular}

Figure 1 below provides additional information on the trends in revisions made to collected amounts, by control channel and over 2013-2015. Figure 1a underlines that the sharp decline in adjustments between 2013 and 2014 is primarily attributable to a decrease in revisions made on declarations routed to the yellow channel, which was not compensated for by an increase in revisions made on red channel declarations the same year. This decline may come from an improvement in compliance or a reduction in the performance of customs (controls). Considering the red channel, despite a slight increase in upward revisions made by customs in 2014 on collected amounts, the magnitude of revised amounts in 2015 returned to its 2013 level. Figure $1 \mathrm{~b}$ reveals, for the declarations slated for the red channel, a significant increase in the average amount adjusted per declaration between 2013 and 2015. This improvement was nevertheless insufficient to offset the substantial drop in the total number of 
revisions. All in all, this evidence suggests that the decreasing trend in revisions made on yellow channel declarations was not offset by a durable increase in revisions made on red channel declarations and therefore supports the claim that in Gabon, the overall efficiency of customs controls has decreased over time.

\section{Figure 1. Annual trend in revisions, in CFA francs (yellow and red channels)}

a) Total revised amounts related to declarations routed to yellow and red channels

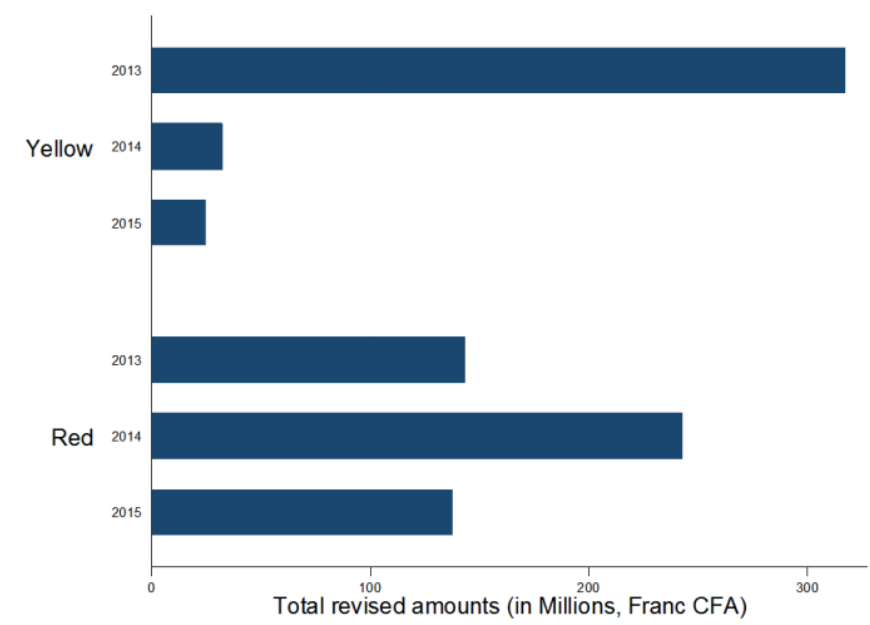

b) Average revised amount per non-compliant declaration routed to yellow and red channels

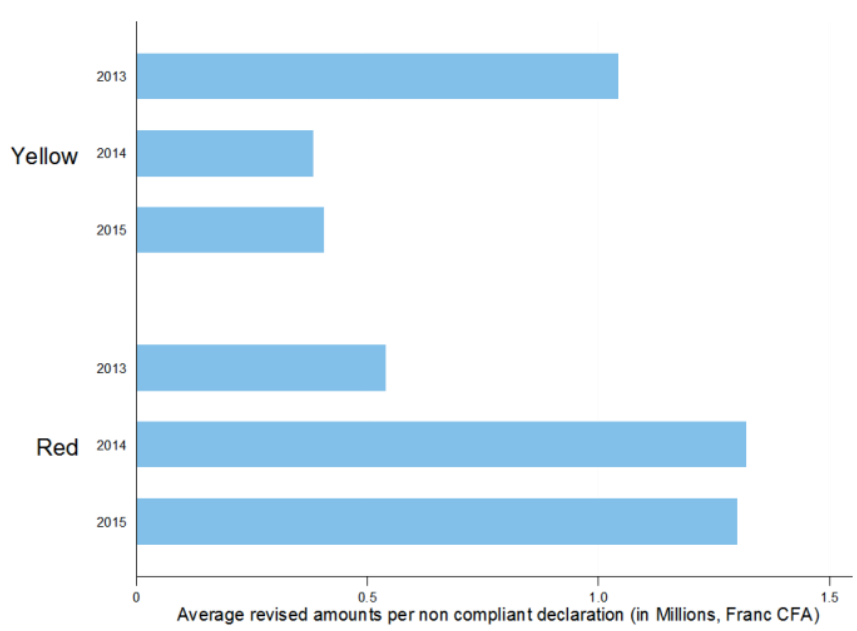

\subsection{Fraud records are mostly related to undervaluation}

In this sub-section, we proceed to the breakdown of fraud records by type of infraction. Considering that the amounts collected $r$ depend on the import unit value $v$, quantity imported $q$ and effective tax rate $t$ - that is, $r=v \times q \times t-$ and that the tax rate is a function of the products' classification (HS), 
the product's origin, and the product's tax regime - that is $t=f(H S$; origin; regime $)$, we can better identify how the detected frauds have affected the amounts collected by Gabon customs. In fact, the data enabled us to compute the annual frequency of revised declarations, decomposed by type of infraction: on the import's unit value $v$, on the import's weight or unit quantity $q$, and on the import's tax regime, origin and HS6 code (affecting the effective tax rate $t$, $c f$. supra). The resulting breakdown of the frequency for each type of infraction is reported in figure 2. Given that the determination of the transaction value $v$ is extremely challenging, specifically in a weak institutional environment, statistics unsurprisingly stress that fraud records are mostly related to the undervaluation of imported items, thereby reducing amounts collected and customs revenue. It is worth mentioning that the second and third most common tax evasion techniques are, respectively, import misclassification and underreporting of imported quantities (through misreported unit quantities or weight). Revisions related to infractions regarding the product's origin or on the import tax regime are marginal.

As customs misevaluation is the most widespread tax evasion technique in Gabon, we therefore decided, in the rest of the paper, to specifically discuss how to combat this type of fraud more effectively. 
Figure 2. Annual frequency of revised declarations, decomposed by type of infraction

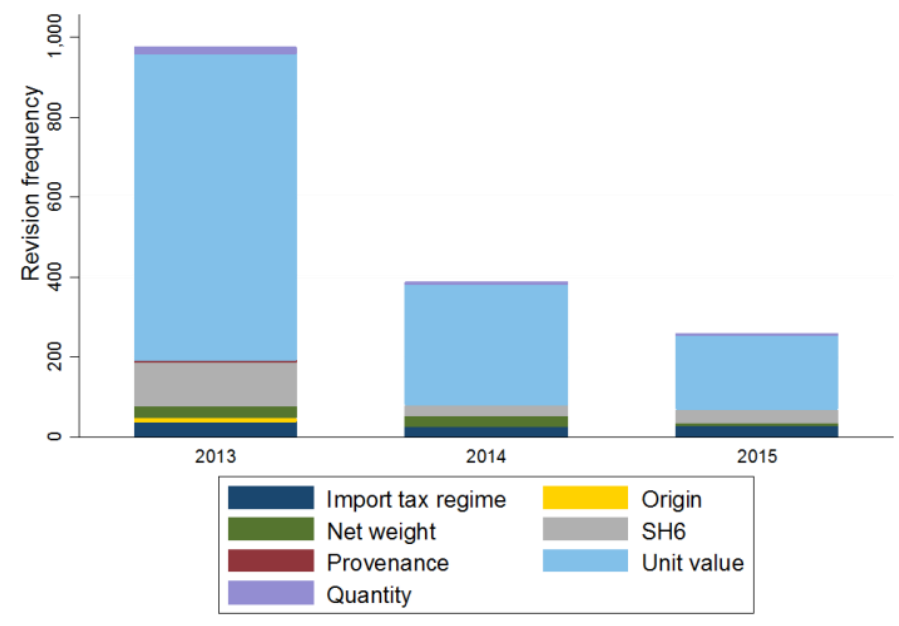

\subsection{In summary}

The analysis of frauds detected by customs during these three years suggests that frontline controls are not very effective because only $1.13 \%$ of the declarations controlled (i.e., routed to the red or yellow channels) were deemed non-compliant. This lack of frontline control performance is accompanied by poor results in terms of facilitation because more than $90 \%$ of declarations were inspected (documentary or physical control).

The project initiated by Gabon customs to develop a risk analysis to reduce the number of controls and to them more effective is therefore quite relevant. However, exploiting only the fraudulent declarations recorded by customs cannot provide the whole picture of fraud at the border, given the low number of detected offences. Consequently, it is necessary to use other sources of information on imports, especially external information from export partners available in international trade databases.

\section{The benefit for customs of using different sources of data to detect fraud: principles and application to Gabon customs}

\subsection{The analysis of discrepancies in trade data (or mirror data analysis)}

\subsubsection{A tool used to detect and measure customs fraud}

The discrepancy in international trade data refers to the difference between the customs (export) value registered by the exporting country and the customs (import) value registered by the importing 
country for the same flow of goods (see, e.g., Ferrantino et al. (2012)). While the Trade gap refers to the difference in value (see equation (1) presented below), the Weight gap refers to the difference in quantity (see equation (2)). ${ }^{5}$ If both countries apply the transaction value as the primary method for customs valuation, then in an ideal setting and ignoring differences attributable to transportation costs, the import customs value and the export customs value should be the same. Discrepancies arise if the value declared by the exporter and the value declared by the importer are different; in other words, if the importer and/or exporter misdeclare(s) to customs the value of goods, then it follows that the difference between the export value and the import value is different from zero. Although the exporter usually has few incentives to make a non-compliant declaration because exports are commonly not subject to restrictions or taxes, the importer has still incentives to misstate the value of goods to reduce the amount of taxes and duties to be paid. This is why many studies assume that discrepancies in trade data are mainly attributable to a non-conforming declaration made by the importer ${ }^{6}$. The revenue loss resulting from this harmful practice is therefore the Trade gap multiplied by the effective tax rate on imports.

Trade gap $=$ Declared export value - Declared import value

Weight gap $=$ Declared export weight - Declared import weight

In practice, a fraction of the discrepancies in international trade data are due to freight and insurance costs. Indeed, whereas the export value is usually registered free of these costs (i.e., free-on-board), the import value should include freight and insurance costs. ${ }^{7}$ Given the abovementioned sources of discrepancies, Chalendard et al. (2017) are in favour of introducing a margin of error (approximately

\footnotetext{
${ }^{5}$ For more details about the basic methodology, see Cantens (2015).

${ }^{6}$ However, it should be stressed that the exporter may, for various reasons (capital flight, imperfections in the VAT reimbursement mechanism, etc.) mis-declare the value of its exports. For example, Ferrantino et al. (2012) have revealed that exporters in China have undervalued their exports to avoid paying VAT. In practice, since exports were expressed FOB (free on board) and imports CIF (cost, insurance and freight), the discrepancy between the exported value and the imported value is consequently slightly negative.

${ }^{7}$ Other factors may also create small discrepancies. According to the literature, differences may also be attributable to the following. Several structural and logistical factors have been proposed in the literature to (partially) explain the discrepancies observed in the mirror data factors: classification differences between exporting and importing countries (Nitsch, 2012; Gaulier and Zignago, 2010), classification errors (Bhagwati, 1964; Jean and Mitaritonna, 2010), imperfect conversion between currencies (Carrère and Grigoriou 2015), goods' transit time (Bhagwati, 1964;, Yeats, 1995), transshipments and reexports (Hummels and Lugovskyy, 2006; Ferrantino and Wanget al., 201208), or even the weakness of exporting countries' export declaration control system (Stoyanov, 2012).
} 
$15 \%) .{ }^{8}$ They also recommend considering relatively aggregated units of analysis as the reliability of export data available on COMTRADE decreases with the level of disaggregation. ${ }^{9}$

\subsubsection{A tool for identifying declarations that should be selected for ex post audits}

Because the Trade gap is based on the final imported value, that is, after revisions made by customs, this indicator represents "untreated" fraud. Untreated fraud comprises fraud not yet detected by the customs administration (due to a performance gap in frontline customs controls) and fraud detected but voluntarily unreported by the inspector (due to a lack of evidence and/or collusion (Sequeira (2016)). For these two cases of fraud, the post-clearance unit is still able to correct the declaration because the legislation authorizes the customs administration to carry out ex post audits several years after the customs clearance (usually three years).

In this context, the mirror data analysis may be extremely useful to orient ex post audits. Indeed, the results of the mirror data analysis for time $t-k$ could be used to establish a post-clearance audit programme at time $t$ to address declarations registered at time $t$ - $k$. However, it is worth noting that due to delays in obtaining up-to-date export data - COMTRADE data are not available in real-time incorporating the results of the mirror data analysis in the frontline risk analysis system might be inefficient. Indeed, given that any risk analysis system orienting the incoming declarations towards an immediate control channel must be based on the current risk of fraud to be efficient, risk analysis must primarily rely on frequently updated selection criteria, i.e., not on the results of an analysis of discrepancies in trade data.

\subsection{Contribution of the mirror data analysis to Gabon customs support}

\subsubsection{Databases}

Gabon customs does not have direct access to trading partners' data. However, in the last few years, a United Nations platform (UN COMTRADE) has provided bilateral trade data (including export data)

\footnotetext{
${ }^{8}$ Introducing a $15 \%$ margin of error means that an imported value between 0.85 and 1.15 times the exported value will be considered to be similar to the exported value.

${ }^{9}$ E.g., (i) section-year, (ii) HS2-year or (iii) HS4-year.
} 
at a highly disaggregated level (HS6 level). ${ }^{10}$ Given that the export values provided by COMTRADE (hereafter the "mirror data") are expressed in US dollars, import values (expressed in CFA francs in the Gabon customs database) were therefore converted into US dollars.

The analysis covers 2013 and 2014 and includes the major products cleared by the main Gabon customs office (i.e., the port of Owendo-Libreville), representing 53\% of imports for home use. We only use data from Owendo-Libreville because reliable information on fraud records was only available for this office. ${ }^{11}$

\subsubsection{The results of the mirror analysis study confirm that the most taxed products should be better monitored}

Portfolio choice models of tax evasion stress that incentives to evade taxes increase with the tax rate (Allingham and Sandmo, 1972). Consistent with this theoretical prediction, figure 3 underlines that products in the highest taxation quartiles (excl. value-added tax (VAT)) are associated with a higher number of fraud records. Unsurprisingly, figure 4 confirms that customs makes the highest upward revisions for products offering greater gains from evasion, i.e., heavily taxed products. ${ }^{12}$ Overall, figures 3 and 4 stress that the highest-taxed products represent the riskiest imports despite of quasisystematic inspections.

Surprisingly, figure 5 highlights that the rate of non-control did not substantially vary according to the level of taxation - the latter being a relevant proxy for customs evasion according to the previous figures - suggesting that the benefits of customs risk management in Gabon were extremely low during the period considered.

\footnotetext{
${ }^{10}$ Countries typically transmit on an annual basis their international trade statistics to the United Nations Statistics Division. However, it is worth mentioning that a small number of countries, primarily oil and developing countries, do not transmit data to the platform.

${ }^{11}$ Lacking available data for adjustments made by the other offices, only the imports handled by the Owendo-Libreville office were considered in the analysis. Owendo-Libreville is Gabon's main customs office (clearing more than half of releases for consumption). To reduce the impact of excluding the other offices, it was decided to only consider the products for which the port of Owendo-Libreville cleared more than two thirds of imports through customs (in value).

${ }^{12}$ These results are consistent with the conclusions of the econometric analysis conducted by Stasavage and Daubrée (1988) on the determinants of (detected) customs fraud in Senegal and Mali; they show that that high levels of taxation encourage fraud.
} 
Finally, figure 6 shows that the "remaining fraud to be processed" (i.e., the Trade gap) is positively correlated with the taxation rate. This correlation indicates that despite (quasi-)systematic inspections, products presenting the highest risk of fraud before frontline customs controls are also the riskiest products after frontline controls. This result confirms that the effectiveness of frontline controls was extremely low in Gabon during the period 2013-2014. To correct these failures, the post-clearance unit should therefore first launch ex post audits on firms importing the highest-taxed products, i.e., the most non-compliant firms.

Figure 3. Frequency of fraud records by import taxation quartile (excl. VAT)

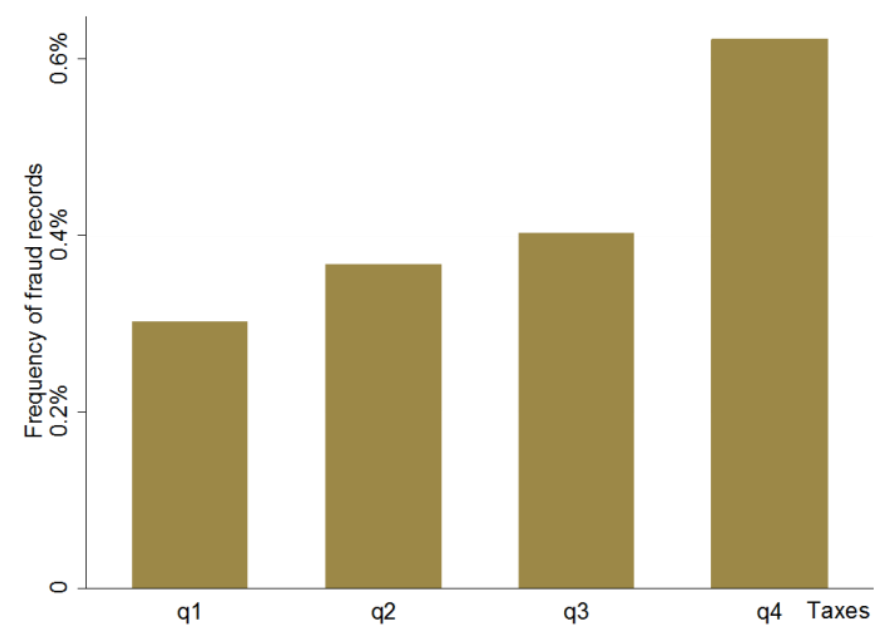

Notes: unit of analysis: HS4 year. Study period: 2013.-2014.

Figure 4. Average upward revision by import taxation quartile (excl. VAT)

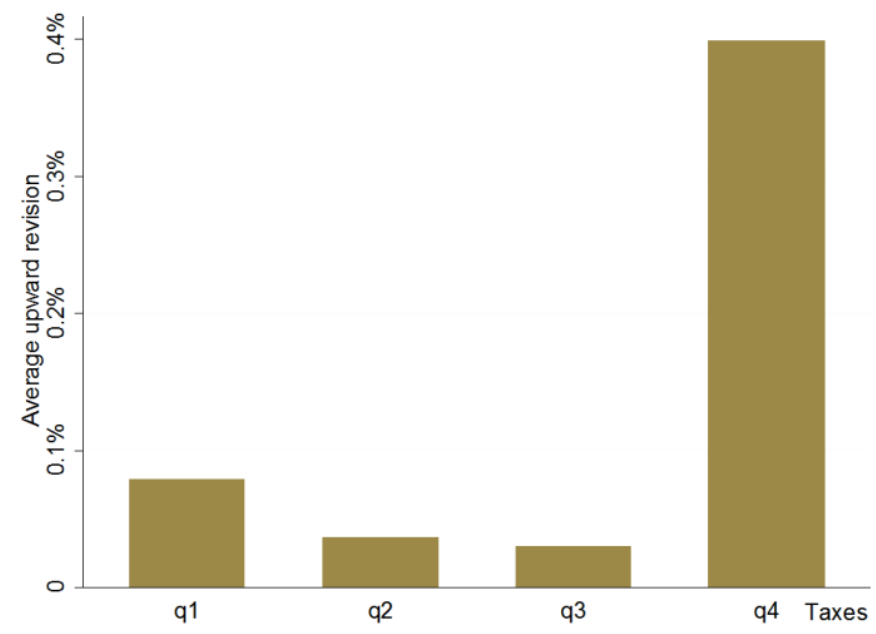


Figure 5. Rate of control by import taxation quartile (excl. VAT)

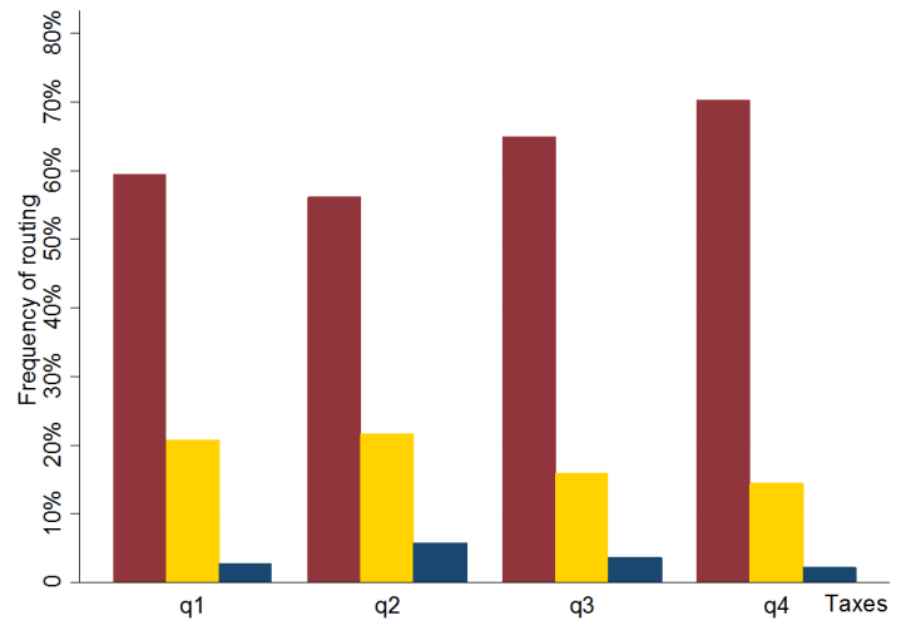

Notes: Unit of analysis: HS4 year. Study period: 2013-2014. The frequency of frontline physical control (red channel) is represented in red. The frequency of documentary control (yellow channel) is represented in yellow. The frequency of non-inspection is represented in blue.

Figure 6. Trade gap by import taxation quartile (excl. VAT)

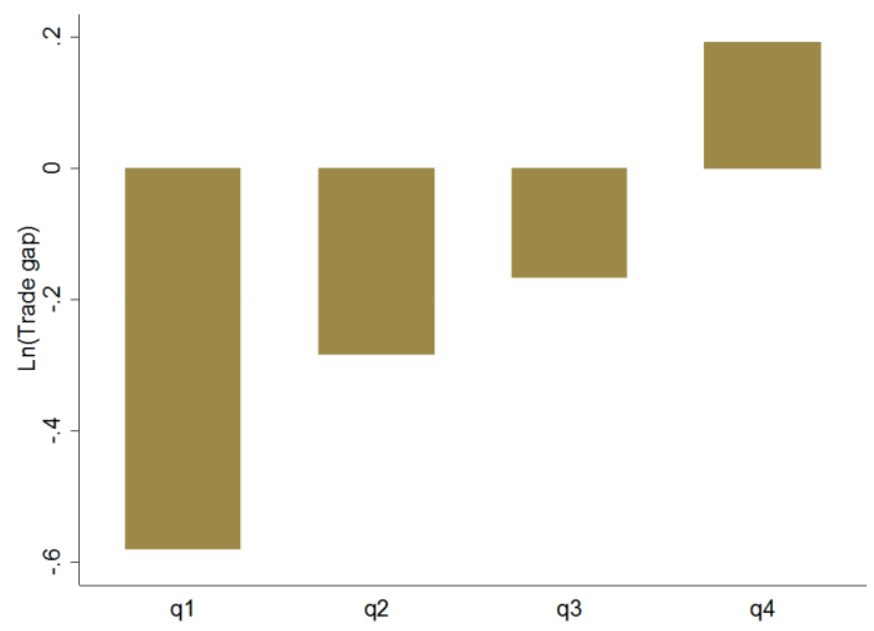

Notes: unit of analysis: HS4 year. Study period: 2013-2014. The variable Ln (Trade gap) is the logarithm of the difference between the declared export value and the declared import value. Due to differences in registration methods between exports and imports, note that the variable Ln (Trade gap) is negative in the absence of undervaluation and positive in the presence of undervaluation. 


\subsubsection{The mirror data analysis identifies high-risk imports that were not fully treated by frontline customs officers: illustration}

This subsection presents two case studies - imports of fats and oils (HS2 chapter: 15) and imports of beverages (HS2 chapter: 22) - that illustrate the value added of adopting mirror data analysis to more effectively combat customs fraud.

As stressed by Chalendard et al. (2016), calculating ratio indicators for each product might be extremely useful for the determination of fraud scenarios (undervaluation and/or underreporting of quantities and/or smuggling). Based on available data, it is possible to compute the ratio of values and the ratio of weights. Assuming that the value reported by the customs of the exporting country is a good proxy for the transaction value, the ratio between the import value and the export value provides an estimate of the magnitude of fraud. While a ratio close to one suggests an absence of fraud on the value, a ratio close to zero suggests the presence of major fraud. These indicators are formally defined below:

Value ratio $=\frac{\text { Value initially declared by importer }}{\text { Value }(\text { final }) \text { reportedby the exporting country's customs }}$

Weight ratio $=\frac{\text { Weightinitiallydeclaredbytimporter }}{\text { Weight }(\text { final }) \text { reportedby the exporting country's customs }}$

For the abovementioned HS chapters, table 5 presents discrepancy indicators (that is, the Trade Gap and the Weight gap) and ratio indicators (that is, the Value ratio and the Weight ratio). Given that the Weight ratio is close to one ( 0.91 for fats and oils, 1.05 for beverages), this indicates that, for these chapters, nearly all shipments declared at the country of exportation were also declared in Gabon (importing country). Therefore, it suggests that quantities were truthfully reported in Gabon. For the value of goods, the mirror analysis indicates that unit values declared in Gabon were noticeably lower 
than those declared at the country of exportation because the ratio of values is lower than one $(0.75$ for fats and oils, 0.89 for beverages). ${ }^{13}$

In summary, contrasting customs data with COMTRADE data for these two HS chapters yields (i) a ratio of weight close to one and (ii) a ratio of values below unity. This suggests that, on average, Gabonese importers under-declared the unit value of imported goods falling into HS2 chapters 15 and 22. These damagingd practices substantially reduced customs revenues, as shown by equation (5), inducing losses estimated at USD 3.5 million for fats and oils (HS2 chapter: 15) and USD 7.2 million for beverages (HS2 chapter: 22). ${ }^{14}$

Tax losses $=$ Trade Gap $x$ Effective tax rate

The variable Effective tax rate is defined as the sum of taxes collected by customs divided by the retained customs value.

Table 5. Presentation of selected results from the mirror data analysis

\begin{tabular}{|c|c|c|c|c|c|c|}
\hline $\begin{array}{c}\text { HS2 } \\
\text { HS4 }\end{array}$ & "Label & $\begin{array}{c}\text { Trade gap (USD } \\
\text { millions) }\end{array}$ & $\begin{array}{l}\text { Value } \\
\text { ratio }\end{array}$ & $\begin{array}{l}\text { Weight } \\
\text { ratio }\end{array}$ & $\begin{array}{c}\text { Effective } \\
\text { tax rate }\end{array}$ & $\begin{array}{c}\text { Estimated } \\
\text { losses (USD } \\
\text { millions) }\end{array}$ \\
\hline 15 & Fats and oils & 15.8 & 0.75 & 0.91 & 0.22 & 3.48 \\
\hline 15.11 & $\begin{array}{l}\text { Palm oil and its } \\
\text { fractions }\end{array}$ & 16.4 & 0.66 & 0.83 & 0.26 & 4.26 \\
\hline 22 & $\begin{array}{l}\text { Beverages, } \\
\text { alcoholic liquids, } \\
\text { etc. }\end{array}$ & 12.8 & 0.89 & 1.05 & 0.56 & 7.17 \\
\hline 22.04 & Fresh grape wines & 12.2 & 0.71 & 1.20 & 0.56 & 6.83 \\
\hline
\end{tabular}

Table 5 highlights that the tax losses related to imports of fats and oils (HS2 chapter: 15) are mostly attributable to the undervaluation of imports of palm oil (HS4: 15.11). The HS4 code 15.11 "Palm oil and its fractions, whether or not refined, but not chemically modified" covers two HS8 codes, i.e.,

\footnotetext{
${ }^{13}$ Note that, in practice, due to the difference in registration methods - while exports are registered free-on-board (i.e., the export value does not include freight and insurance costs), import values include freight and insurance costs - a Value ratio larger than 1 is expected.

${ }^{14}$ Since the Trade gap is by nature slightly negative due to the difference in registration methods (cf supra), note that it is not abnormal to obtain larger estimates of tax losses at the HS4 level than estimates at the HS2 level.
} 
crude palm oil (HS8:15.11.10.00) and refined palm oil (HS8: 15.11.90.00). While the importation of crude palm oil (HS8: 15.11.10.11) is not taxed in Gabon, the importation of refined palm oil (HS8: 15.11.90.00) is taxed at $44.5 \%$. Such a high tax rate on imports of refined palm oil strongly incentivizes unscrupulous importers to undervalue imports of palm oil or to declare refined palm oil as crude oil. The customs statistics displayed in Table 6 stress that undervaluation occurred because the average value per kilogram declared for refined oil was substantially lower than that declared for crude oil. Such harmful practices occurred despite systematic physical and documentary controls. As expected, imports of the untaxed oil (crude oil) did not appear to be undervalued, as the average declared value per kilogram is slightly greater than the international reference value defined in Rotterdam. ${ }^{15}$

\section{Table 6. Palm oil import statistics}

\begin{tabular}{cccccc}
\hline Palm oil & Year & $\begin{array}{c}\text { Declared imported } \\
\text { value } \\
\text { (USD millions) }\end{array}$ & $\begin{array}{c}\text { Declared imported } \\
\text { weight (thousands of } \\
\text { metric tons) }\end{array}$ & $\begin{array}{c}\text { Value per kg } \\
\text { (USD/kg) }\end{array}$ & $\begin{array}{c}\text { Effective } \\
\text { tax rate }\end{array}$ \\
\cline { 3 - 6 } Crude & 2013 & 5.47 & 5.52 & 0.99 & $0 \%$ \\
Refined & 2014 & 3.33 & 3.55 & 0.94 & $0 \%$ \\
& 2013 & 11.30 & 15.40 & 0.74 & $41 \%$ \\
& 2014 & 5.76 & 10.10 & 0.57 & $41 \%$ \\
\hline
\end{tabular}

Note: statistics for imports of palm oil cleared through customs by the Owendo-Libreville office. All imports were physically inspected (i.e., routed to the red channel).

Regarding beverages (HS2 chapter 22), table 5 underlines that tax losses are primarily attributable to imports of fresh grape wine (HS4: 22.04). Indeed, the Trade gap "Fresh grape wine" accounts for 95\% of the Trade gap "Beverage". Given the heterogeneity in wines, we decided to restrict the analysis of declaration behaviours to the importation of a well-known and well-identified wine: Champagne (HS8: 22.04.10.10). Because Champagne is a luxury good, importers face a heavy tax burden ${ }^{16}$. Specifically, to get the goods cleared, economic agents must pay $93 \%$ of the declared value of imported bottles to customs, creating a strong incentive to undervalue. Even though imports of

\footnotetext{
${ }^{15}$ The average price (cost, insurance and fret) for palm oil destined for Rotterdam was $0.86 \mathrm{USD} / \mathrm{kg}$ in 2013 and 0.82 USD/kg in 2014, source: World Bank Commodity Price data.

${ }^{16}$ On top of that, notice that the use of the word "Champagne" is regulated as this specific wine benefits from a protected geographical indication.
} 
Champagne were, at the border, quasi-systematically controlled - more than $95 \%$ of shipments were inspected - table 7 highlights that these imports were declared, on average, at 4.5 US dollars per litre. This value seems to be very low. Indeed, based on the numbers provided by the Association of Producers of Champagne, we estimated the average price of 2014 exports of Champagne at 19.53 Euros per litre ${ }^{17}$. Although undervaluation appears to be sizeable, no cases of non-compliance were reported. This finding will be further discussed in subsection 4.3.

Table 7. Champagne import statistics

\begin{tabular}{ccccc}
\hline \hline Year & $\begin{array}{c}\text { Declared imported value } \\
\text { (millions USD) }\end{array}$ & $\begin{array}{c}\text { Declared imported } \\
\text { weight (thousands } \\
\text { of metric tons) }\end{array}$ & $\begin{array}{c}\text { Value per } \\
\mathbf{k g} \text { (USD/kg) }\end{array}$ & $\begin{array}{c}\text { Rate of non-control } \\
\text { (blue channel) }\end{array}$ \\
\cline { 2 - 5 } $\mathbf{2 0 1 3}$ & 1.73 & 0.38 & 4.5 & $2 \%$ \\
$\mathbf{2 0 1 4}$ & 1.57 & 0.35 & 4.4 & $5 \%$ \\
\hline \hline
\end{tabular}

Note: statistics for imports of Champagne cleared through customs by the Owendo-Libreville office.

In this section, we highlighted the benefits of exploiting various sources of information (internal customs data, mirror trade data) to increase the effectiveness of custom risk analysis and hence the performance of customs administration. In the following section, we combine these different sources to define and calculate synthetic indicators of customs' effectiveness.

\section{Synthetic indicators of customs' effectiveness}

\subsection{Customs control effectiveness indicators}

\section{Principles}

Mirror data can be matched with internal customs data on fraud records to assess customs' performance in terms of value controls. Specifically, it is possible to compare the value of the ratio

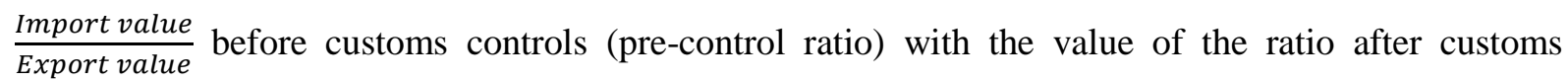

\footnotetext{
${ }^{17}$ Database https://www.champagne.fr/assets/files/economie/bulletin_expeditions_vins_champagne2014.pdf
}

source : 
controls (post-control ratio). To illustrate the benefits of such an approach, figure 7 presents an analytical framework that compares, for each HS code, the share of estimated undetected fraud before and after frontline controls. While the x-axis represents the initial customs fraud, that is, the value initially reported by the importer or his representative (relative to the value registered by the exporting country), the y-axis represents the final customs fraud, that is, the value registered by Gabon customs after customs controls (relative to the value registered by the exporting country). In the case of upward revisions made on a specific product, the $\mathrm{y}$-axis ratio values are greater than the $\mathrm{x}$-axis ratio values. The corresponding observation point is therefore located above the $45^{\circ}$ diagonal line passing through the origin (the red line displayed in figure 7). If the observation point is situated on the $45^{\circ}$ diagonal line, it means that customs have not detected any fraud on this product. When the y-axis value is close to one (i.e., near the horizontal green line), customs inspections are extremely efficient. Likewise, when the $x$-value is close to one (i.e., near the vertical orange line), it indicates that importers are honest.

To integrate the results of post-clearance audits, it is recommended this synoptic view of the effectiveness of customs valuation controls be updated as frequently as possible. Following this approach makes it possible to track improvements in the effectiveness of controls.

Figure 7. Synoptic view of the effectiveness of customs valuation controls 


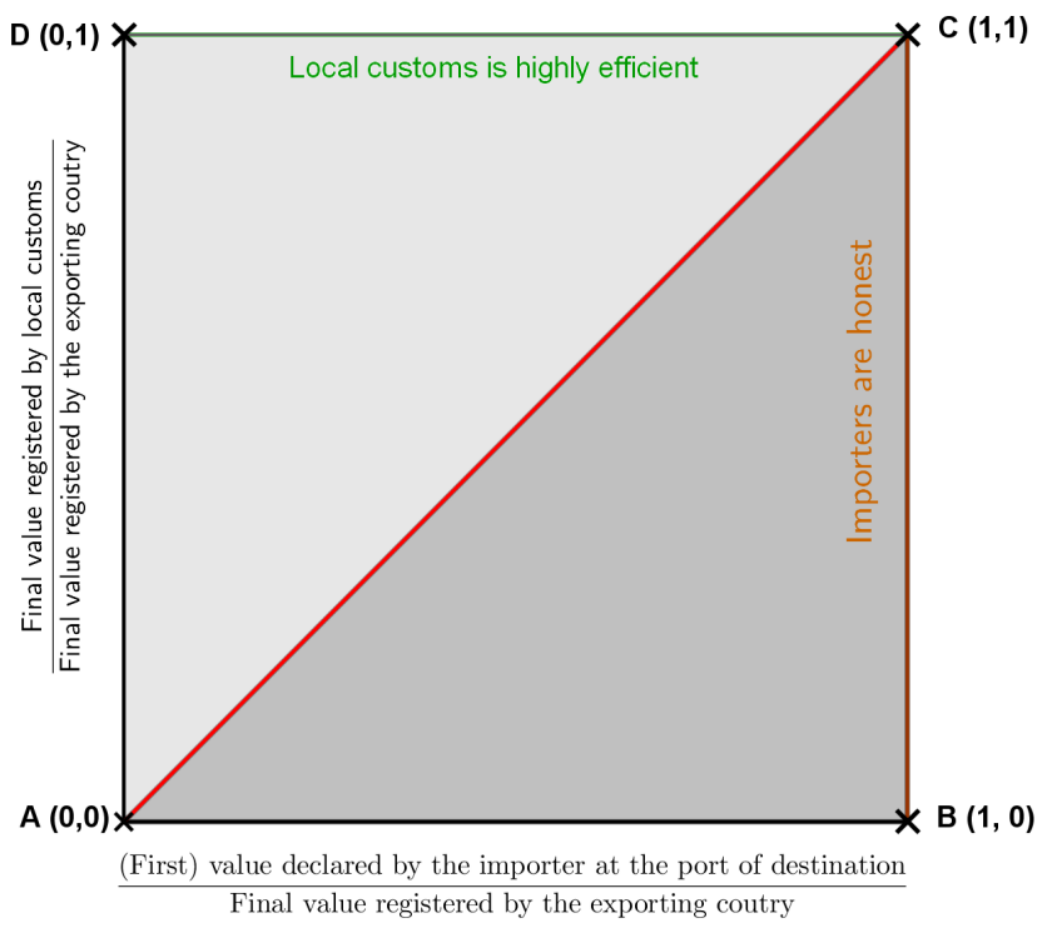

\section{Synthetic picture of the Gabon customs' action}

Figure 8 displays the synoptic view of the effectiveness of Gabon customs, which is obtained by matching mirror trade data with information on revisions made during customs controls. Because a large fraction of observations are located on the diagonal, customs intervention did not increase the declared value of imports for most tariff headings. Despite this relative ineffectiveness, it is worth mentioning that the efficiency of customs controls was higher on some specific tariff headings, in particular on the imports of wickerwork (the outlier above the diagonal in figure 8). For this product in 2013, customs increased the value by more than $25 \%$, thereby helping to substantially reduce the Trade gap corresponding to this heading. By contrast, customs' action also resulted, due to value cuts among other actions, in lowering the customs value for some headings. This was especially the case for printed materials, images, engravings and photographs imported in 2014. For this product, customs' actions were totally counterproductive because they increased the trade gap by 435,000 US dollars (for a revenue loss of 110,000 US dollars). 


\section{Figure 8. Synoptic view of the effectiveness of Gabon customs valuation controls}

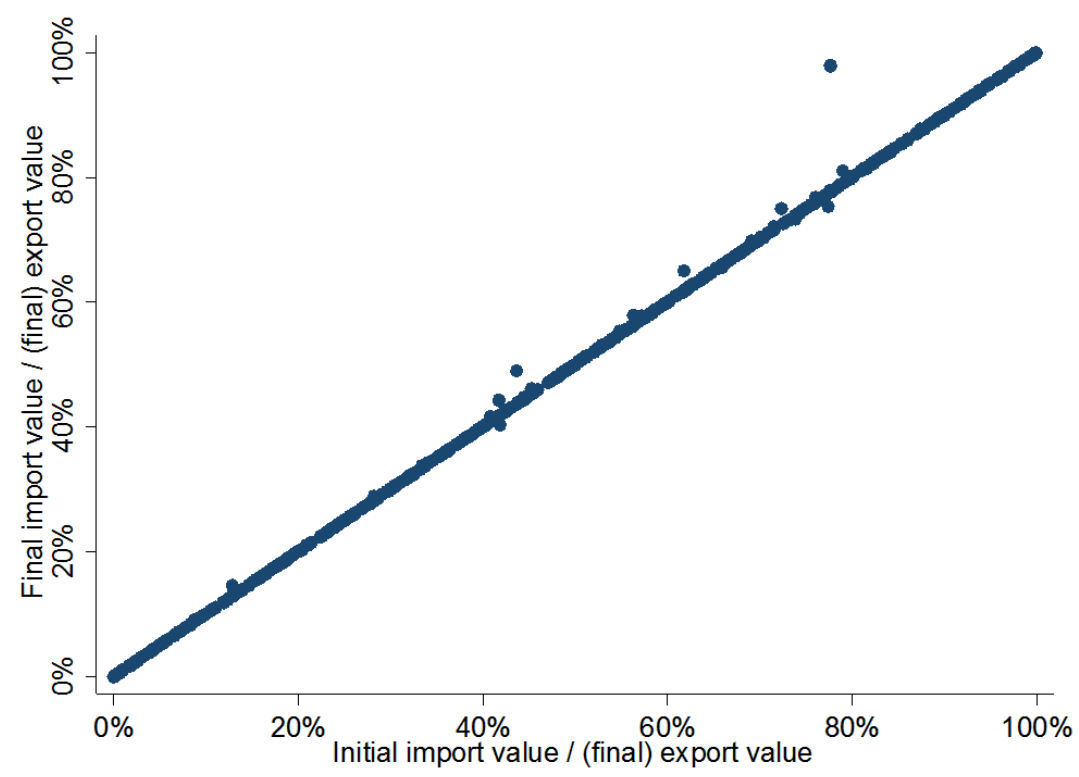

Notes: analysis unit: HS4 year. Study period: 2013.-2014

The synoptic view of the effectiveness of customs valuation controls can be usefully supplemented with a synthetic measurement of the effectiveness of customs. For each HS4 code, this indicator measures the gap between the size of revisions actually made by the Gabon customs administration on import values and the size of revisions a fully effective inspection would have yielded, taking as reference value the value reported by the exporting country. In its basic formulation, the customs control effectiveness (CUCOEF) indicator is computed as follows:

$\mathrm{CUCOEF}_{\text {base }}=\frac{\sum_{H S 4=0101}^{9706}\left(\text { Ratio }_{\text {final value_HS4 }}-\text { Ratio }_{\text {initial value_HS4 }}\right)}{\sum_{H S 4=0101}^{9706}\left(1-\text { Ratio }_{\text {final value_HS4 }}\right)}$

where

$$
\begin{aligned}
& \text { Ratio }_{\text {initial value } \mathrm{SH} 4}=\frac{\text { Value initially declared by the importer }{ }_{\mathrm{HS} 4}}{\text { Reference value }(\text { final }) \text { reported by the exporting country } \text { customs }_{H S 4}} \\
& \text { Ratio }_{\text {final value } \mathrm{SH} 4}=\frac{\text { Final value retained by the importing country's customs }{ }_{H S 4}}{\text { Reference value reported by the exporting country's customs } s_{H S}}
\end{aligned}
$$

This indicator ranges from -1 (maximum direct ineffectiveness) to 1 (maximum direct effectiveness) ${ }^{18}$. Ratios and summations are computed at the HS4 level. CUCOEF ${ }_{\text {base }}$ is therefore the ratio of the difference between the import values initially declared by importers before inspections (expressed as a

\footnotetext{
${ }^{18}$ The use of the term "direct" underlines the fact that this indicator does not take into account the dissuasive component of controls (indirect effect).
} 
share of the import value declared by exporters) and the final import value after custom inspections (expressed as a share of the import value declared by exporters multiplied by the effective tax rate) over the difference between the no-fraud situation ${ }^{19}$ and the final import value after customs controls. In other words, it relates the actual revision made by customs on the import value to the revision that would have been necessary to reach the no-fraud situation.

In a second step, to better account for the influence of undervaluation in customs declarations over revenue collection, the indicator can be weighted by the share of import values at export associated with each HS4 code in the total import value at export. The resulting $\mathrm{CUCOEF}_{\text {underval }}$ indicator is computed as follows:

$\mathrm{CUCOEF}_{\text {underval }}=100 \times \frac{\sum_{H S 4=0101}^{9706}\left(\text { Ratio }_{\text {final value_HS4 }}-\text { Ratio }_{\text {initialvalue_HS4 }}\right)^{\alpha_{H S 4}}}{\sum_{H S 4=0101}^{9706}\left(1-\text { Ratio }_{\text {final value_HS4 }}\right)^{\alpha_{H S 4}}}$

with

$\alpha_{H S 4}=\frac{\text { Import value at export }{ }_{H S 4}}{\sum_{H S 4=0101}^{9706} \text { Import value at export }_{H S 4}}$

In a last step, from the viewpoint of monitoring customs revenue mobilization performance, a third version considering the tariff structure applied to imported products is calculated. To the relative import value weight, this version adds a weight corresponding to the relative effective tariff associated with each HS4 code. It yields the following formula:

$\mathrm{CUCOEF}_{\text {revenues }}=100 \times \frac{\sum_{H S 4=0101}^{9706}\left(\text { Ratio }_{\text {final value_HS4 }}-\text { Ratio }_{\text {initial value_HS4 }}\right)^{\beta_{H S 4}}}{\sum_{H S 4=0101}^{9706}\left(1-\text { Ratio }_{\text {final value_HS4 }}\right)^{\beta_{H S 4}}}$

With

$\beta_{H S 4}=\frac{\text { Import value at export }{ }_{H S 4}}{\sum_{H S 4=0101}^{9706} \text { Import value at export }_{H S 4}} \times \frac{\text { Effective tariff }{ }_{H S 4}}{\text { Average effective tariff }}$

And

Average effective tariff $=\frac{1}{N_{H S 4}} \sum_{H S 4=0101}^{9706}$ Effective tariff ${ }_{H S 4}$

Effective tariff $f_{H S}$ is the average effective customs tariff applied to imports associated with a given HS4 code, and effective tariff average is the average effective customs tariff applied to all imports. $N_{H S 4}$ corresponds to the number of HS4 codes associated with imports. The CUCOEF $F_{\text {revenues }}$ indicator

\footnotetext{
${ }^{19}$ The ratio equals 1 , as the final import value equals the value reported by exporters.
} 
therefore overweights (respectively underweights) and undervalues (respectively over-values) the HS4 codes with substantial (respectively small) revenue losses.

\subsection{Customs control effectiveness indicators: application to Gabon customs}

Table 8 displays the three versions of the $\mathrm{CUCOEF}$ indicator. The $\mathrm{CUCOEF}_{\text {base }}$ indicator shows that the Gabon customs' actions towards reducing the Trade gap was almost nil for 2013 and 2014. Interestingly, when Trade Gaps are weighted by the relative value of imports, the assessment of the customs' effectiveness slightly improves, with a $\mathrm{CUCOEF}_{\text {undervaluation }}$ score lying between 0.10 and 0.13 . Therefore, this indicator reveals that revisions, although infrequent, are targeting HS codes representing a greater share in the total value of imports.

Finally, when the CUCUOEF is weighted in view of monitoring customs revenue mobilization performance, that is, by taking into account the relative value of imports and the tariff structure, the indicator slightly increases: $\left(\mathrm{CUCOEF}_{\text {revenues }}\right.$ equals 0.17$)$. This figure suggests that Gabon customs $\mathrm{i}$ revenue oriented: it tends to target its controls towards imports with higher revenue mobilization potential.

Table 8. Effectiveness of Gabon customs

\begin{tabular}{lccc}
\hline \hline $\begin{array}{l}\text { Type of CUCOEF } \\
\text { indicator }\end{array}$ & $\mathbf{2 0 1 3}$ & $\mathbf{2 0 1 4}$ & Period [2013;2014] \\
\cline { 2 - 4 } Base & 0.0015 & -0.0002 & 0.0006 \\
Undervaluation & 0.1381 & 0.1056 & 0.1218 \\
Revenues & 0.1857 & 0.1568 & 0.1712 \\
\hline \hline
\end{tabular}

\subsection{Discussion}

As in other African countries, some value abatements were granted during the study period in Gabon to certain categories of importers or to those who requested such abatements. This practice aimed to lower the tax burden without modifying the tax rate by reducing the tax base. These advantages were 
mostly granted following a specific request: they were exceptional or $a d$ hoc partial exemptions ${ }^{20}$, but in these cases, the resulting value registered in customs was less than the transaction value, leading to a "legal" undervaluation. The resulting Trade gap was therefore officially approved by the authorities. Abatements correspond to a lawful tax benefit granted, i.e., a tax expense and not fraudulent behaviour by the importer requiring a reassessment on the part of the customs authority. In such a case, the benefits of the mirror data analysis to improve the effectiveness of value controls (i.e., to carry out the necessary upward adjustments) are challenged.

In Gabon's customs administration, no coding is provided to identify these abatements, which precludes any traceability ${ }^{21}$. For example, it is impossible to know whether the low values registered by customs for Champagne are due to a fraudulent practice or to an abatement in value officially granted to a specific operator. Therefore, the practice of value abatement limits the scope of the mirror data analysis.

The contribution of the mirror data analysis to customs administrations therefore depends on the reliability of the data, especially the data from the customs information system. In particular, the problem of value abatements should encourage them to reassess certain procedures to improve the quality of their database. At the same time, authorities should gradually abandon any practices that are incompatible with effective domestic revenue mobilization and the principle of fair competition.

\section{Conclusion}

This paper first presents, for a Sub-Saharan African country, stylized facts on the (lack of) effectiveness of frontline customs controls. We also demonstrate that customs should diversify their sources of information to improve the fight against fraud and the monitoring of their performances As part of their modernization efforts, customs administrations in developing countries should therefore rely more on data analytics, especially to develop efficient risk-based management systems.

\footnotetext{
${ }^{20}$ In Benin, this practice was used more systematically with the application of so-called "consensual" values to favor imports to Nigeria. For further information on Benin-Nigeria (informal) trade, see Golub (2012)

${ }^{21}$ For example, in Cameroon, specific additional codes (A05 - A60) are used in the information system to monitor these kinds of benefits.
} 
This paper stresses that the use of customs data on fraud records for routing declaration in inspection channels reaches its limits in terms of "revenue" effectiveness. In fact, this approach aims to improve customs efficiency based merely on offences detected by customs officers (Geourjon et al., 2013), which represent only a small fraction of overall fraud on imports. The use of mirror trade data addresses this drawback by providing information on undetected fraud, which can be matched with information on detected fraud to give a comprehensive picture of customs controls performance.

Thus, several benefits are gained from using external sources of information such as mirror trade statistics. First, the mirror data analysis is an efficient tool for targeting ex post audits towards highrisk transactions that escaped the frontline controls. The case of Gabon is enlightening because it demonstrates the complementarity of the two successive risk analysis and selectivity approaches; the first based primarily on customs data, mainly targeting frontline controls, and the second based on discrepancies in trade statistics to target ex post audits. Then, based on the combination of mirror trade statistics and data on customs frauds, we propose indicators measuring and monitoring the performance of frontline and ex post customs controls. Because these indicators are built on clear, objective and transparent criteria, their introduction will promote efficiency and virtuous behaviour in customs administrations, which in turn will support both trade facilitation and revenue mobilization as preconized by the Addis Ababa Action Agenda.

\section{Acknowledgement}

The authors wish to thank Mr. Alain Paul Ndjoubi Ossamy, Director General of Gabon customs, who authorized the Ferdi to use the customs databases, without which this work could not have been carried out. Audrey-Anne de Ubeda, Research Assistant at Ferdi, participated in this work. The authors thank her for her help. The authors are also grateful to the Editor and the referee for their valuable comments. Last, the authors thank the participants in the PICARD-2016 conference of the World Customs Organization, and in particular Thomas Cantens, for their insightful remarks. 


\section{Bibliography}

Allingham, M. G., and A. Sandmo (1972) : "Income tax evasion : A theoretical analysis," Journal of Public Economics, 1(3), 323-338.

Anderson, J., and E.VanWincoop (2003)."Gravity with Gravitas: A solution to the border puzzle", The American Economic Review, 93,170-192.

Anson, J., Cadot, O., and M. Olarreaga (2006). "Tariff evasion and customs corruption: Does preshipment inspection help?" The BE Journals in Economic Analysis and Policy, 5(1), 1935-1682.

Baier, S., and J. Bergstrand (2001). "The growth of world trade: tariffs, transport costs, and income similarity", Journal of International Economics, 53, 1-27.

Bhagwati, J. (1964). "On the under invoicing of imports", Oxford Bulletin of Economics and Statistics, 27, 389-397.

Cantens, T. (2015)."Mirror Analysis: Customs Risk Analysis and Fraud Detection", Global Trade and Customs Journal, 10, 207-2016.

Carrere, C., and Grigoriou, C. (2015). "Can mirror data help to capture informal international trade?" Development Policy Series P123, FERDI. Chalendard, C. (2017). «Using internal and external sources of information to reduce customs evasion », ICTD Working Paper 62.

Chalendard, C., Raballand G., and A. Rakotoarisoa (2016). "The use of detailed statistical data in customs reform: the case of Madagascar”, Policy Research Working Paper $n^{\circ} 7625$, The World Bank, Washington, D.C.

Dequiedt, V., A-M. Geourjon, and G. Rota-Graziosi (2009). "Les programmes de vérification des importations à la lumière de la théorie de l'agence », Afrique Contemporaine, 230, 151-166.

Dutz, M. (2000). "The Use and Usefulness of PSI Services", in Pre-Shipment Inspection: Past Experiences and Future Directions, Trade and Enterprise Paper 2 London: Commonwealth Secretariat. 
Fernandes, A.M., Hillberry, R., and A. Mendoza Alcántara (2015)."Trade Effects of Customs Reform: Evidence from Albania", Policy Research Working Paper $n^{\circ} 7210$, The World Bank, Washington D.C.

Ferrantino, M. J., Liu, X., and Z. Wang (2012). "Evasion behaviors of exporters and importers: Evidence from the US-China trade data discrepancy", Journal of International Economics, 86(1), $141-157$.

Fisman, R., and S.J. Wei (2004). "Tax rates and tax evasion: evidence from «missing imports » in China", Journal of Political Economy, 112(2), 471-496.

Gaulier, G., and S. Zignago (2010). "BACI: International tradedatabase at the product-level: the 19942007 version", Document de travail CEPII $n^{\circ} 2010-23$, CEPII.

Geourjon, A.M., and B. Laporte (2005). "Risk management for targeting customs controls in developing countries: a risky venture for revenue performance?", Public Administration and Development, 25(2),105-113.

Geourjon, A.M., and B. Laporte (2012).“ La gestion du risque en douane: premières leçons tirées de l'expérience de quelques pays d'Afrique de l'Ouest", Revue d'Economie du Développement, 3, 67-82.

Geourjon, A.M., Laporte, B., Coundoul, O., and M.Gadiaga (2013). "Inspecting Less to Inspect Better: the Use of Data Mining For Risk Management by Customs Administrations", in Eds. T. Cantens, T., Ireland, R. and G. Raballand, Reform by Numbers: Measurement Applied to Customs and Tax Administrations in Developing Countries, The World Bank, Washington D.C.

Golub, S. (2012). "Entrepot trade and smuggling in West Africa: Benin, Togo and Nigeria". The World Economy, 35(9), 1139-1161.

Han, C-R., and R. McGauran (2014). "Tracing trails: implications of tax information exchange programs for customs administrations", World Customs Journal, 8(2), 3-14.

Hummels, D., and V. Lugovskyy (2006)."Are matched partner trade statistics a usable measure of transportation costs?", Review of International Economics, 14(1), 69-86. 
Javorcik, B., and G. Narciso (2008). "Differentiated products and evasion of import tariffs", Journal of International Economics, 76(2), 208-222.

Jean, S., and C. Mitaritonna, (2010). "Determinants and pervasiveness of the evasion of custom duties", Document de travail CEPII n²010-26, CEPII.

Johnson, N.D. (2001). "Committing to Civil Service Reform: The Performance of Pre-Shipment Inspection Under Different Institutional Regimes", Policy Research Working Paper No.2594, The World Bank, Washington D.C.

Keen, J. (2004).Changing Customs: Challenges and Strategies for the Reform of Customs Administration. International Monetary Fund, Washington.

Laporte, B. (2011). "Risk management systems: using data mining in developing countries' customs administrations", World Customs Journal, 5(1), 17-27.

Levin, J., and L. Widell (2014). "Tax evasion in Kenya and Tanzania: Evidence from missing imports", Economic Modelling, 39, 151-162.

Limao, N., and T. Venables (2001). "Infrastructure, geographical disadvantage, transport costs, and trade", World Bank Economic Review, 15(3), 451-479.

Martincus, C.V. (2016). Out of the Border Labyrinth: An Assessment of Trade Facilitation Initiatives in Latin America and the Caribbean, Inter-American Development Bank.

Martincus C.V., Carballo J., and A. Graziano (2015). "Customs", Journal of International Economics, 96, 119-137.

Mishra, P., Subramanian, A., and P. Topalova (2008). "Tariffs, enforcement, and customs evasion: evidence from India”, Journal of Public Economics, 92, 1907-1925.

Nitsch, V., (2012). Trade mispricing and illicit flows, in: Draining development? Controlling flows of illicit funds from developing countries, ed. Reuter, P., The World Bank, Washington D.C.

Raballand, G., Cantens, T., and G. Arenas (2013). "Mirror Trade Statistics: A Tool to Help Identify Customs Fraud", in eds. T. Cantens, R. Ireland and G. Raballand, Reform by Numbers: Measurement 
Applied to Customs and Tax Administrations in Developing Countries, The World Bank, Washington D.C.

Rijkers, B., Baghdadi, L., and G. Raballand (2015). "Political Connections and Tariff Evasion: Evidence from Tunisia", The World Bank Economic Review, 31(2), 459-482.

Sequeira, S. (2016). Corruption, Trade Costs, and Gains from Tariff Liberalization: Evidence from Southern Africa", The American Economic Review, 106(10), 3029-3063.

Stasavage, D., and C. Daubrée (1998). "Determinants of Customs Fraud and Corruption”, Documents de travail du Centre de Developpement de l'OCDE, no. 138, OECD, Paris.

Stoyanov, A. (2012). "Tariff evasion and rules of origin violations under the Canada-U.S. Free Trade Agreement", Canadian Journal of Economics, 45(3), 879-902.

Van Dunem, J. E., and C. Arndt (2009). "Estimating border tax evasion in Mozambique", The Journal of Development Studies, 45(6), 1010-1025.

WCO, 1999, Revised Kyoto Convention: http://www.wcoomd.org/ie/En/Topics_Issues/FacilitationCustomsProcedures/Kyoto_New/Content/co ntent.html.

Yang, D. (2008) "Integrity for Hire: An Analysis of a Widespread Customs Reform," The Journal of Law and Economics, 51(1): 25-57.Worku, T. J., Mendoza, P., and J.L. Wielhouwer (2016). "Tariff evasion in sub-Saharan Africa: the influence of corruption in importing and exporting countries", International Tax and Public Finance, 23(4), 741-761.

Yeats, A. (1978). "On the accuracy of partner country trade statistics", Oxford Bulletin of Economics and Statistics, 40(4), 341-61.

Yeats, A. (1995). "Are partner country statistics useful for estimating « missing » trade data?", Policy Research Working Paper $n^{\circ} 1501$, The World Bank, Washington D.C. 